\title{
Sleeping with the enemy? Biodiversity conservation, corporations and the green economy
}

\author{
William M. Adams ${ }^{1}$ \\ University of Cambridge, UK
}

\begin{abstract}
This article explores the surprising closeness and apparent warmth of the relations between biodiversity conservation organisations and corporations. It argues that in this paradoxical engagement, conservationists are exhibiting an extreme form of pragmatism - a willingness to 'sleep with the enemy.' The article considers the implications of these arrangements using the metaphor of a Faustian Bargain, a deal with the devil to acquire power in exchange for the soul. It considers the lure to conservationists of the logics underlying collaboration in the forms of market-based neoliberal conservation and the green economy in the light of the long-standing tradition of opposition in the face of the destructive engagement between capitalism and nature. It considers the benefits of conservation of its Faustian bargain, and explores its consequences.
\end{abstract}

Key Words: biodiversity conservation, neoliberal conservation

\section{Résumé}

Cet article explore la proximité surprenante et la chaleur apparente des relations entre les organismes de conservation de la biodiversité et les entreprises. Il fait valoir que dans cet engagement paradoxal, les conservateurs présentent une forme extrême de pragmatisme - une volonté de «dormir avec l'ennemi». L'article considère les implications de cette relation en utilisant la métaphore d'une négociation faustienne, un accord avec le diable pour acquérir le pouvoir en échange de l'âme. Elle considère l'attrait pour les conservateurs des logiques qui sous-tendent la collaboration dans les formes de conservation néolibérale basée sur le marché et l'économie verte, compte tenu de la longue tradition d'opposition face à l'engagement destructeur entre le capitalisme et la nature. Il considère les avantages de la conservation de cette négociation faustienne et en explore les conséquences.

Mots clés: conservation de la biodiversité, conservation néolibérale, économie verte

\section{Resumen}

Este artículo explora la inesperada cercanía y aparente calidez, en las relaciones entre las corporaciones y las organizaciones dedicadas a la conservación de la biodiversidad. Se argumenta que en esta paradójica relación, los conservacionistas muestran una forma extrema de pragmatismo - una disposición de 'dormir con el enemigo'. El artículo considera las implicaciones de esta disposición a través del uso de la metáfora del 'pacto faustiano', un pacto con el diablo para adquirir poder a cambio del alma. Se toma en cuenta el atractivo que para los conservacionistas representa la lógica de una colaboración en la conservación neoliberal basadas en el mercado y una economía verde. Esto, a la luz de una larga tradición de oposición frente a la destructiva relación entre capitalismo y naturaleza. Se consideran los beneficios en cuanto a conservación de este pacto faustiano, y se exploran además sus consecuencias.

Palabras clave: conservación con base en mercado, neoliberalismo, economía verde

\footnotetext{
${ }^{1}$ Dr. William M. Adams, Moran Professor of Conservation and Development, Department of Geography, University of Cambridge, CB2 3EN, UK. Email: wa12 "at" cam.ac.uk. Web: https://thinkinglikeahuman.com/. Acknowledgements: many thanks to Connor Cavanagh and two referees for comments on the manuscript. This is the second article in Connor Cavanagh and Tor Benjaminsen (eds.) 2017. "Political ecologies of the green economy", Special Section of the Journal of Political Ecology, 24: 200-341.
} 


\section{Introduction}

At the World Parks Congress in Durban in 2003, Sir Robert Wilson, chair of the global mining company Rio Tinto explained how leaders of ten of the world's largest mining companies had met in London in 1998. He said: "we discussed how our industry was misunderstood and misrepresented. Some suggested we needed an education campaign. Others said a PR campaign. But others said: 'We've done all that. It doesn't work. What we have to do is change perceptions by changing our behaviour"' (Colchester 2003). ${ }^{2}$

Environmentalists tend to doubt the possibility of distinguishing between 'changing behavior' (some kind of real 'green economy', Brockington 2012; UNEP 2011) and simply changing stories about behaviour (some version of 'greenwashing', Lyon and Maxwell 2011; Mulligan 1999). Industries, particularly the extractive industries, have been seen by environmentalists as the drivers of environmental destruction for the last century and a half, since the birth of the modern environmental movement. They still occupy the top spot: as the veteran conservationist Michael Soulé notes, "globalization of intensive economic activity has accelerated the frenzied rush for energy and raw materials and is devouring the last remnants of the wild, largely to serve the expanding, affluent, consumer classes in industrialized and developing nations." (2013: 896)

Yet since the turn of the Millennium, there has been a remarkable engagement between biodiversity conservation organisations and industrial corporations (Chapin 2004). Nowhere has this been more apparent than in mining, which has seen a series of initiatives in the space between environmentalist critique and corporate performance (Macdonald 2010a). In 1998, a 'Global Mining Initiative' was established "to provide sustainable leadership for the mining and minerals industry in the areas of our economic, social and environmental performance" (McNeilly 2000). In an address in Australia in 2000, R J McNeilly, Executive Director and President BHP Minerals, said this initiative was:

...not a public relations exercise - the public quickly sees through PR campaigns. Nor is it an advertising campaign - these have failed in the past. Nor is it an education program - these have had uneven success. The GMI is about the more substantive issue of mining's tangible contribution to the world in which we live. (McNeilly 2000)

In pursuit of this objective, a succession of initiatives was created, growing from each other with bewildering speed. In 1997, Conservation International published Reinventing the well, the report of a task force on "minimizing the environmental and social impacts of oil development in the tropics" (Rosenfeld et al. 1997), and three years later followed it with Lightening the lode, on large-scale mining (Rosenfeld Sweeting and Clark 2000). In 1999 the World Business Council for Sustainable Development (WBCSD) began a Mining, Minerals and Sustainable Development project with of its member companies (Anglo American, BHP Billiton, Codelco, Newmont, Noranda, Phelps Dodge, Placer Dome, Rio Tinto) (Griffiths 2010), from which grew the Mining, Minerals and Sustainable Development Project (MMSD) ${ }^{3}$, a research collaboration between the WBCSD and IIED in London from 2000-2002, which in turn led to the report Breaking new ground (IIED 2002). In 2001, 23 mining and metals companies and 35 national and regional mining associations and global commodity associations formed the The International Council on Mining and Metals (ICMM). Its stated purpose was "to act as a catalyst for performance improvement in the mining, minerals and metals industry", specifically with respect to sustainable development and social, economic and environmental progress. ${ }^{4}$ And it was from this now well-developed platform that Sir Robert Wilson of Rio Tinto addressed the 2003 Parks Congress in Durban (MacDonald 2010a).

In five short years, mining and minerals had seemingly gone from enemy of biodiversity conservation to valued friend and supporter. The engagement has continued, indeed grown. Many leading international conservation NGOs have some kind of 'partnership' with corporations. Thus Rio Tinto, which has worked

${ }^{2}$ http://multinationalmonitor.org/mm2003/03november/nov03corp3.html

${ }_{3}^{3}$ www.iied.org/mining-minerals-sustainable-development-mmsd

${ }^{4}$ http://www.icmm.com 
with the US organisation Conservation International since 1999, launched a corporate biodiversity strategy at the IUCN Congress in Bangkok in 2004, committing itself to the goal of achieving a "net positive impact" on biodiversity (Conservation International 2008). The company saw collaboration with 'biodiversity partners' as critical in achieving this aim, noting that "the CI-Rio Tinto partnership is critical to achieving outcomes that neither could achieve working alone."

The depth and strength of the engagement between mining and minerals industry has been noted before, as one example of a wider corporate-conservation engagement (e.g. Chapin 2004; Norris in press; Robinson 2011a). Given that conservationists remain doggedly passionate about nature and hostile to the drivers of its decline, why are they willing to share platforms, board membership, and apparently values with corporations? How has enmity turned into cohabitation? This article explores these questions, focusing on the arguments conservation uses to justify belief in the positive fruits for their interests arising from such partnerships.

\section{Sleeping with the enemy}

There is a very substantial literature on the engagement between biodiversity conservation and neoliberalism (e.g. Büscher et al. 2012; Igoe et al. 2010; MacDonald 2010b). This article seeks to contribute to this debate by exploring the nature of conservation's development of alliances with corporations, its willingness - to 'sleep with the enemy.' It argues that conservationists are turning a blind eye to their own past and to the working of neoliberal capitalism, showing a remarkable willingness to entertain future risks to biodiversity from the outworking of neoliberalism.

In a rapprochement with capitalism, conservation could be said to be making a Faustian bargain (c.f. Maron et al. 2012). In the central European folk story of Faust, the hero makes a deal with Mephistopheles (the devil) to receive power and knowledge in return for his soul. Faust achieves much, but the devil returns for what is due. I would suggest that the bargain between conservationists and corporations is of this kind. In this case, conservationists hoping to gain power and influence are giving up their innocent objection to the destructiveness of capitalism. This same deal underpins the last four decades of mainstream environmentalism, from the wish-fulfillment of sustainable development to contemporary market-based approaches to managing human engagements with nature.

In exploring conservation's Faustian bargain, I will proceed by reviewing the two key transformations that have taken place in conservation beliefs and actions under the broader processes of neoliberalization. The first is the rise of market-based strategies in conservation, and the associated reframing of conservation and the destruction of nature that accompanies the attempt to deliver conservation through market mechanisms. The second transformation involves the idea of the 'green economy', a capitalist economy that is environmentally sustainable (effectively attempting to deliver conservation through the work of corporations and consumerism). I then explore the history of conservation as a movement in opposition to the destructive relationship between capitalism and nature, which is what makes the contemporary move to embrace the private sector such a puzzle. I ask why conservationists make such a Faustian bargain with corporations, and explore the benefits and consequences consider the implications of their pragmatism.

\section{Market-based conservation}

The literature on neoliberal conservation leaves little space for doubt about the ways in which concern for nature has become transformed by neoliberalism, and imbricated within corporate strategies. Neoliberalism needs to be understood both as a political economic regime within which capitalism has expanded and diversified, and as a framework for public life within which capital has re-imagined and represented itself, and within which environmentalism has been reformulated, and arguably co-opted. Neoliberal conservation, the application of market-based approaches to conserving nature, "shifts the focus from how nature is used in and through the expansion of capitalism, to how nature is conserved in and through the expansion of capitalism" (Büscher et al. 2012:4; Holmes and Cavanagh 2016). Neoliberal conservation overlooks capitalism's environmental contradictions and instead presents capitalism as the key to future ecological sustainability (Igoe et al. 2010). 
In the closing decades of the twentieth century, market-based strategies became central to thinking about not only biodiversity conservation, but also sustainability more widely. There was "a vigorous reinsertion of the economic dimensions of sustainability" from the mid-1990s onwards (Owens 2003). Increasingly, the market came to be seen as "the most important mechanism for mediating between people, and regulating their interaction with the environment" (Low and Gleeson 1998:12). Nature became increasingly interpreted as 'natural' capital, and sustainability, in economic terms, as maximising flows of income while maintaining the stock of capital from which it comes. In the process nature was opened up to 'green-grabbing' (Corson and MacDonald 2012; Fairhead et al. 2012). Such 'grabs' took the form of physical land grabs, and the privatization of rights to nature (including in the shape of novel forms of commodity, such as 'carbon credits' and derivatives, Sullivan 2013).

The reformulation of nature into the language of capital came to occupy centre stage in conservation after the turn of the Millennium, at the heart of the intellectual industry around concepts like ecosystem services and policies such as Payments for Ecosystem Services. The mainstreaming of Ecosystem Services was effected through programmes such as The Economics of Ecosystems and Biodiversity (TEEB), between 2008 and 2012 (Corson and MacDonald 2012). TEEB's mission was "to make nature economically visible", in national programmes such as the UK National Ecosystem Assessment, thus making an explicit link between the state of nature and the benefits provided to society and continuing economic prosperity. Through market-based approaches, economics could achieve for conservation what oppositionism had not.

Braun (2015) argues that the neoliberalization of nature (and in turn of environmentalism) represents an 'environmental fix' for capitalism in response to a crisis of accumulation because of environmental impacts and social movement opposition. Complex linked processes of privatization, marketisation, and financialisation have begun to transform relations between capital and nature. In the process they have refashioned conservation as the chief moral arbiter of those relationships (Apostolopoulou and Adams 2017). Processes of deregulation and re-regulation have refigured nature in terms of 'services' and 'natural capital', and in doing so have reworked conservation into an industry that converts nature into forms that "capital can see" (Robertson 2006). Thus for nature to be 'saved', conservation is brought to the market, and private investment harnessed to the task of conserving nature (Sullivan 2013): nature "is conserved in and through the expansion of capitalism" (Büscher et al. 2012: 4).

It is clear why businesses engaged in the 'institutional capture' of conservation: their need to sustain revenues, secure reserves of resources and influence policy, particularly to ensure the predictability needed to enable them to plan effectively (MacDonald 2010b). 'Grabbing green', the process that redefines nature in ways that promote accumulation, merged the languages of ecology and economics and the institutions of the state and private sector, environmentalism and capitalism (MacDonald 2013: 47).

Novel strategies such as biodiversity offsetting now explicitly link biodiversity protection to the facilitation of corporate access to natural resources (Apostolopoulou and Adams 2017). Thus Hackett (2015, 2016) describes the 'direct twinning' of forest conservation and oil sands development in Alberta, Canada, where mining corporations fund land purchase for conservation NGOs outside the zone where environmental and social impacts are concentrated. So far, the impacts of neoliberal market-based discourse on financial flows in conservation have been limited (Dempsey and Suarez 2016). However, the cultural and political effects have been considerable, changing the way conservation imagines itself, and legitimizing and reinforcing capitalism accumulation. This discourse feeds "an emerging consensus among conservationists that they must now court, rather than confront, entrenched power structures, established regimes of capital accumulation, and private capital itself" (Dempsey and Suarez 2016: 267).

\section{Conservation and the 'Green Economy'}

In parallel with the engagement of biodiversity conservation in neoliberalism and associated adoption of market-based languages and strategies, the wider environmental movement has been reformed around the concept of the 'green economy' (MacDonald 2013). This lay at the heart of the United Nations Conference on Sustainable Development, Rio de Janeiro, in June 2012 (Rio + 20). In 2011, UNEP published Towards a green economy (UNEP 2011), a report whose models predicted growth in global income and employment 
driven by both pubic and private investment (Brockington 2012). It argued that the 'green economy' could "deliver improved human well-being and social equity, while significantly reducing environmental risks and ecological scarcities" (UNEP 2011: 16). The green economy was portrayed as a cornucopia of benefits. The Green Economy Coalition supports "an economy that provides a better quality of life for all within the ecological limits of the planet" (www.greeneconomycoalition.org). UNEP's initiative was soon followed by other organizations, including the OECD (2011) and World Bank (2012).

The idea of the 'green economy' articulated at Rio + 20 grew directly from more than three decades of thinking about sustainable development, most notably in the report of the World Commission on Environment and Development (the Brundtland Report) in 1987, and the two previous UN meetings that grew from it (the Rio Conference in 1992, and the World Summit on Sustainable Development in Johannesburg in 2002, Adams 2009). As Low and Gleeson pointed out in 1998, the fundamental feature of 'the green economy' is that it is capitalist. MacDonald (2010: 517) described sustainable development in the 1980s as "a compromise conceptual device" to address the environmental crisis of consumption and the associated crisis of capitalism (c.f. Braun 2015). It is a good example of what Prudham (2009: 1594) describes as "a mash-up of environmentalism with capitalism."

While the idea of the green economy served as a strategy to engage economists, finance ministers and financial investors in the task of protecting nature, it also served to harness nature to support the economy (Corson et al. 2015). Market-based environmentalism involved acceptance of "well-designed and regulated markets as efficient and flexible mechanisms for achieving 'sustainable development"' (Castree and Henderson 2014: 22). MacDonald (2010b) argues that business regarded UNCED in 1992 as a threat, neutralized through a process of engagement, involving a series of initiatives, including the World Business Council for Sustainable Development. The UNCED Secretariat "positioned the best-organized and financially powerful independent sectors as privileged working partners" (MacDonald 2010b: 524), allowing businesses a privileged position in the process of the Convention on Biological Diversity (which grew from Rio), and subsequently in the formulation of the idea of the 'Green Economy' (Brockington 2012, MacDonald 2013).

Under sustainable development, and especially in the formulation of the 'green economy', there were not only opportunities for conservationists, but also for corporations. 'Green' technologies such as solar panels and 'smart' digital devices depend on rare earth elements and minerals like coltan, creating an associated mining boom (Jeffries 2015). The president of the World Business Council for Sustainable Development, a coalition of 170 international companies, said in 2012,

A capitalist is somebody who optimizes returns from capital employed. The mistake is that the current economic model is solely focused on optimizing the return on financial capital. We need to add two more elements of capital: natural capital and social capital, and tell capitalists to go and optimize that. (Bakker 2012)

It is the prospect of win-win outcomes, including secure future profit, that motivate moves towards corporate sustainability. In this formulation, environmental care can make good business.

Optimism about novel win-win solutions involving corporations is widespread in conservation. An Ecomodernist manifesto, published in 2015 by an US think-tank, offered an upbeat optimistic vision of 'ecomodernization', to achieve "vastly improved material well-being, public health, resource productivity, economic integration, shared infrastructure, and personal freedom" (Asafu-Adjaye et al. 2015: 28). This demands "accelerated technological progress", and in turn "the active, assertive, and aggressive participation of private sector entrepreneurs, markets, civil society, and the state" (p. 30). MacDonald (2013: 55) describes the 'green economy' as "the pinnacle of ecomodernism." It is a world of wished-for win-win solutions, attempting to move beyond the "binaries (growth or nature, prosperity or biodiversity) that have marginalized conservation" (Lalasz et al. 2011). Marris et al. (2011) suggest that "the Anthropocene does not represent a failure of environmentalism. It is the stage on which a new, more positive and forward-looking environmentalism can be built." 
Even recognizing the broad appeal of neoliberalism and ecomodernism, there is a puzzling irony in the timing of conservation's embrace of industry. The end of the twentieth century was a time when the unsustainability of current industrial and consumption models had been recognized, not least in the context of anthropogenic climate change. As Arboleda argues of the current era, it had become obvious to all observers that "the metabolic exchanges of matter, energy and capital required to feed the contemporary urban world have been distorted and up-scaled to the point that they have now reached a hypertrophic, global extent" (Arboleda 2015: 2).

\section{Capitalism, nature and its conservation}

The modern conservation movement developed within the frame set by the western industrial and consumption models that dominated the nineteenth and twentieth centuries, shaped in turn by colonial and post-colonial developmentalism, globalized concern about poverty, and sustainability. Under neoliberalization, these same models are reworking contemporary conservation ideas and practice.

Formal conservation organizations began to be established in the late nineteenth century in North America and Europe. While many powerful new ones were added over the $20^{\text {th }}$ century (The Nature Conservancy in 1948, WWF in 1961, Conservation International in 1987), many of those early organizations endure. The common concern of their founders was their opposition to environmental change. Thus the New York Zoological Society, in its rescue of the American Bison, shot to the brink of extinction in the Great Plains; the Society for the Preservation of the Wild Fauna of the Empire in London, in its lobbying for game reserves and national parks in British colonies in Africa; or the National Trust in England and Wales, established to acquire and preserve places of natural beauty and historic interest threatened with destruction (Adams 2004). All represent different responses to the 'loss' of nature.

Without understanding the way capitalism worked, or its power, early conservationists set themselves up against the impacts of capitalist modernity, in the form of industrialisation, urban expansion, over-hunting and collecting. They understood that capitalism was "inherently environmentally unfriendly", even if they did not recognise the Marxist critique of capital that "continuously gnaws away at the resource base that sustains it" (Pepper 1993: 91-92).

Foster argued that capitalism created a "rift" in the "metabolic interaction between man and the earth" (1999: 380; 2000). There is debate as to when capitalism transformed the nature of agriculture's metabolism (sixteenth century 'high farming' doing so long before Liebig's organic chemistry and industrialism). Marx believed that the intensification of agriculture in the nineteenth century brought about an 'irreparable rift' in that social metabolism, involving the decline of soil fertility due to the loss of local nutrient cycling. In European agriculture, the specific problems of fertility were addressed by the application of chemistry to the creation of synthesised phosphates, and by nitrate fertiliser. But the metabolic rift involved in wider capitalism, industrialism, and modernity continued to deepen (Foster 2015). Early conservationists, and their successors, have sought to address the implications of this rift (although not the causes of the rift or the interdependence of environmental transformation and the development of capitalism, Moore 2011).

Conservation in the nineteenth and twentieth centuries was a classic romantic formulation (Veldman 1993). It sought to the protection of pristine nature from people and their destructive effects, especially in what have come to be called 'protected areas': nature reserves, preserves and sanctuaries. Conservation embraced (as it continues to do) a crude binary, between nature wild and pristine (and of great worth), and nature developed, disturbed and desecrated by humanity. As George Perkins Marsh (1864) put it in Man and nature, "man is everywhere a disturbing agent. Wherever he plants his foot, the harmonies of nature are turned to discords. The proportions and accommodations which ensured the stability of existing arrangements are overthrown" (p. 36). Conservationists sought to protect nature's harmonies from these disturbances, both systematically (for example in inter-war campaigns against whaling, or oil pollution, Adams 2004), but most particularly by setting aside the most precious (or their favourite) areas, sequestered in nature reserves against the wider storm of change.

Of course, conservation has never lived up to this oppositional ideal. Brockington and Duffy (2010: 470) suggest that the anti-capitalist line taken by environmentalism of the 1960s and 1970s was "the 
exception, not the rule." MacDonald (2010b: 516) argues conservation "has never really driven environmental agendas", but has been an instrument in much larger political projects of nationalism, colonialism and capitalism. Histories certainly demonstrate the power of these framings very clearly (Adams 2004; Brockington et al. 2008; Neumann 1998). Early conservation activists, like their successors today, were disproportionately well educated, not least in science, and reasonably well off financially. They were the beneficiaries of the very exploitation of nature whose effects they deplored, and the same systems of accumulation and dispossession that powered them.

Yet a preservationist opposition to nature's transformation has always been central to conservation's appeal to its supporters. Conservationists take it as obvious that in "a very short period of human history, and a mere blip of Earth History", capitalism has "altered and destroyed the material world at an unprecedented speed and on a scale previously achieved only by natural evolution or other kinds of (non-human) biophysical change" (Castree and Henderson 2014: 22). Conservation represents an emotional and intellectually superficial response to the changes wrought by capitalism, but it is, nonetheless, an oppositional response.

\section{Conservation's partnerships}

Engagements between corporations and conservation NGOs take many forms. They are characterized by ambitious and optimistic arguments about the potential for positive outcomes from corporate learning and change. Two are described here. The first is the Energy and Biodiversity Initiative (EBI), which ran from 2001 to 2007. This was a partnership between leading global oil companies (BP, ChevronTexaco, Shell and Statoil) and conservation organizations (Conservation International, Fauna \& Flora International, the Nature Conservancy and the Smithsonian Institution). Its stated aim was to "integrate biodiversity conservation into upstream oil and gas development" (http://www.theebi.org). The report Integrating biodiversity conservation into oil and gas development (EBI 2003) was intended to be "a practical guide for building biodiversity protection into the entire spectrum of oil and gas operations, from exploration to decommissioning" (http://www.theebi.org). This report was then disseminated though the member organizations and across the sector (translated into French, Spanish, Portuguese, and Chinese) before the initiative was wound up. The Energy and Biodiversity Initiative website reports that the EBI "has been instrumental in helping companies understand and address biodiversity conservation and it provides an effective framework for the management of biodiversity across multiple industries" (http://www.theebi.org). Whatever benefits the EBI may have brought in terms of the management of oil and gas facilities, it did not prevent the expansion of energetically inefficient tar sands (Hackett 2006), or exploration in the Arctic (Rosenbaum 2015), let alone address the biodiversity impacts of climate change resulting from fossil fuel use.

The second example of conservation-corporate partnership offers an intriguing insight into the possibility of real influence of conservation NGOs on their partners. Fauna \& Flora International launched a partnership in 2008 with the mining corporation Anglo American "to safeguard biodiversity" (Nyul not dated). They "recognised that Anglo American was striving for best practice in biodiversity management", and saw "that helping the company to improve its policies and practices towards biodiversity could create real conservation benefits." They developed a programme of work that they believed (or argued) would improve procedures within Anglo American and enable them to take account of biodiversity in their operations. The partnership came under a severe test over the Pebble Mine, a massive project to open-cast mine gold and copper in Alaska.

Pebble Mine threatened to have very extensive environmental impacts, particularly on Alaska's Sockeye salmon fishery. There was extensive environmental opposition, and questions as to whether the US Environmental Protection Agency would approve the development. In 2013, Anglo-American suddenly pulled out, leaving other partners to continue (Goldenberg 2013). Surely a good test of Anglo American's new found environmental resolve, and Fauna \& Flora International's partnership? Perhaps, but Adams (2015) argues that this was not a simple case of a mining corporation finding an environmental conscience, but actually reflected low falling commodity prices for gold. The Pebble mine would not only be less profitable, but the major hike in production would also reduce the profitability of Anglo American's existing mining 
operations elsewhere. Anglo American therefore lost interest at a time of oversupply: their decision was supported by simple business considerations. Indeed, Adams argues that environmental protests about the mine served the interests of Anglo American (and Rio Tinto, who left the project in April 2014) by providing an exit strategy, and potentially making the Pebble Mine unworkable.

Did the Fauna \& Flora International partnership with Anglo American influence procedures and ideas within the company? The Pebble Mine decision was perhaps good for nature, but it was also good for the sustainability of the profits of leading corporations: a win-win outcome, perhaps, but not necessarily because the corporations had been changed by conservation's engagement. This may not be unusual. Robinson (2011a) suggests that there is little evidence that corporate engagements bear real fruit. As he notes, "[e]ven those companies that have positioned themselves as responsive to concerns have not been able to demonstrate improved conservation outcomes" (Robinson 2011a: 310). Anglo American remains one of Fauna \& Flora International's partners, as does Rio Tinto (Howard 2014b).

\section{Conservation's Faustian bargain}

To understand why conservation organizations have struck their bargain with capital, it is necessary to understand conservation as "an organised political project" (MacDonald 2010a: 257). Whereas in the past conservation has reflected the interests of political projects like nationalism, colonialism and science, MacDonald argues that now private sector businesses are dominant, transforming conservation in ways that accommodate the interests of global capital.

Fundamentally, the idea of a close relationship with private sector organisations reflects very straightforwardly the power of neoliberalism, and its reshaping of conservation. The ideology and practices of conservation are re-imagined around the structure of corporate profit, private accumulation and capital. Mark Tercek, who became President and CEO of The Nature Conservancy after a career Goldman Sachs (rising to Managing Director and Partner) set out in his book Nature's fortune how business leaders could account for nature in financial terms and incorporate that value into the decisions and activities of their business, alongside revenue, costs and return on investment. Along with 'economic progress' this approach would bring 'breakthroughs in conservation', protecting water supplies; enhancing the health of fisheries; making cities more liveable, sustainable and safe (Tercek and J. Adams 2015).

However, accepting the capacity of neoliberalism to transform conservation ideology and practice, it is important to question how this transformation comes to be accepted: what has persuaded conservationists to engage with corporations? Three arguments are important.

First, conservationists feel a sense of desperation. The notion of crisis lies at the heart of the environmentalism of the twentieth and twenty-first centuries (Fairhead et al. 2012). Perceptions of and arguments about crisis stimulate and legitimate 'green-grabbing', and the penetration of market-based approaches into environmental management (Fairhead et al. 2012). Powerful 'crisis' narratives are well established within biodiversity conservation narratives (e.g. Hoag 2010; Kolbert 2014). Indeed, the science at the heart of contemporary conservation debates, conservation biology, is described as a 'crisis discipline', whose relationship to biology is "like that of surgery to physiology and of war to political science" (Soulé 1985: 727).

Second, conservation's engagement with corporations reflects a highly pragmatic stance on biodiversity loss. Robinson (2011: 959) reviews the ethical basis of different conservation strategies, and concludes that choice among different conservation objectives and approaches "must be pragmatic, and respond to the long term potential for sustainability." He suggests that "ideology must be replaced by pluralism in the choice of objectives and approaches", recognizing that different stakeholders have different values, and that therefore conservation choices must be context-specific. A key argument to justify engagement with corporations by conservation organizations is therefore that 'it works' (or they believe it might work). Among large conservation NGOs, the mainstream conservation belief has shifted (Chapin 2004; MacDonald 2010a). The belief has emerged that partnerships with business can work, at least in the specific (and narrow) frame of biodiversity protection. Thus, Fauna \& Flora International state that they 
...believe that one of the most effective ways to protect biodiversity and ecosystem services is to work closely with the very businesses that have the potential to pose the greatest harm. We choose to work with businesses that are committed to reducing their impacts on the environment and businesses that are positioning themselves as market leaders. (Howard 2014a).

The hope is that through partnership and collaboration businesses can be supported "to manage their dependencies and mitigate their impacts on biodiversity and ecosystems in the landscapes where they operate, and to become local role models who encourage other land users within these landscapes to do the same" (Howard 2014a).

A third element of the enthusiasm of conservationists for capitalism is simply that they appear not to understand it, and therefore do not understand what they are doing (c.f. Scales 2014). The risks associated with the pervasive effects of neoliberalism in reframing conservation strategies is abundantly clear to analysts of the 'neoliberal turn' in conservation. Prudham (2009: 1604) encapsulates the problem neatly:

While a market-centered discourse of environmentalism fixates on the most efficient ways to meet given environmental targets, it ignores the systemic production of new environmental problems (new natures) for which there may be no social regulation and no targets, and which leaves unchallenged a political economy whose mantra is growth as an end in itself.

But conservationists, mostly trained as scientists, are untrained in political economy, and lack institutions adapted to learning what they do not know. They ingenuously accept simplistic narratives of 'partnerships' and 'win-win', with scant understanding of what these rhetorical products $d o$. Neoliberalism entrains the passionate would-be protector of nature, their trained scientific mind guileless in the face of forces they cannot name and do not understand: they take at face value the notions that markets are the best way to organize positive change in society, that the wealth and power of corporations can be harnessed for conservation if they only understand the need.

\section{The Bargain's benefits}

Conservation organizations benefit from their engagement with corporations in a range of ways. First, the bargain is, like that of Faust, about power. At the level of the sector, conservationists see corporations as actors with the power to make the decisions on which the future of biodiversity depends. Therefore, to make a difference in the world, they need to engage those whose decisions matter. Traditional strategies involved work with national governments (to pass legislation or declare protected areas). In a neoliberal world, the power of governments has come to seem secondary to that of corporations. On this analysis, it seems logical for conservationists to move to engage directly with corporations, or to broker public-private partnerships. Conservationists therefore engage because they want influence. Robinson (2011a: 310) points out that "the conservation strategy has been for NGOs to engage with the largest and leading companies in a sector with the hope to 'identify the best, and move the rest'." (He also notes "[t]he efficacy of this strategy remains unclear.")

The second way in which corporate relations can benefit individual conservation organizations is in the form of funding and influence. Conservation is everywhere limited by financial resources. Conservation organizations are entirely dependent on external funds, and while some have large memberships, these provide a tiny fraction of operating budgets. In many cases, the existence of members serves primarily as a legitimization exercise, evidence of public support for policies, and a statement of strength that helps attract funding. As MacDonald (2010b) notes, this dependence on external environment "not only makes the control of organizational behaviour possible but almost inevitable": NGOs adapt their strategies and programmes within the envelope of what is fundable. As Holmes (2012) observes, 'philanthrocapitalism' assumes that profit motives make for better philanthropy, and hence more effective conservation. Corporations are key 
financiers of conservation: through direct sponsorship for NGO activities from linked charitable foundations, through support for 'partnership' activities (perhaps involving corporate planning or operations, or a field site relevant to corporate activities), through direct philanthropic support from individuals within corporations (e.g. members of corporate boards, or retired corporate millionaires, Holmes (2012), or through linked forprofit enterprises (business partnerships for example in wildlife tourism enterprises or conservation-endorsed commodity chains). Pergams et al. (2004) showed that conservation spending in the USA was correlated with income and wealth, with philanthropic giving linked to the state of the economy. Conservation has increasingly come to depend on the state of the stock market, harnessed to the churning engine of capital.

The third way in which corporate relations can benefit conservation is in the benefits to individuals within organizations. The presence of corporate executive (or ex-executives) on NGO Boards allows for various forms of formal and informal career mentoring, guidance to 'remuneration committees', and networks of corporate contacts. Corporate support also offers opportunities for career development: all NGOs depend on cash income to develop their programmes, and working in a way that aligns your programme with the interests and activities of corporations is a good way to keep your job and grow your program. Biting a hand that might feed your organization is therefore a risky strategy for career sustainability and progression, conforming programs with corporate interests the reverse.

\section{The Bargain's consequences}

The problem for conservationists seeking a close encounter with corporations is the fundamental nature of capitalism. As Bruce Braun (2015: 1) observes, "Capital is not a source of life, but parasitic on it": Castree and Henderson (2014: 18) ask "how can stocks of finite and renewable resources and iconic sites be protected by an economic system whose hallmark is creative destruction?" If conservation is Faust, the power it wins by its bargain with capitalism is inevitably trivial and transient: ultimately, in the face of capitalism's destruction of nature, conservation will lose.

Relations between corporations and conservation organisations are in no sense equitable. Businesses are enabled to carry forward their work with only marginal changes to corporate strategies. But engagements in the form of sponsorship, agreements and partnerships have a significant effect in "restructuring the ideological and organisational orientation" of conservation organisations (MacDonald 2010a: 297). As Hoffman (2009) observes, influence flows both ways between environmental organisations and businesses actors. Ties are channels of information and resources, but these channels also work in reverse. Environmental NGOs that relate closely to businesses risk their autonomy, risk becoming like businesses, fully entwined with neoliberalism, as critics repeatedly point out (e.g. Büscher et al. 2012; Igoe et al. 2010).

As a result, despite the numerous examples, 'partnerships' with industry do not in any obvious way 'work' for conservation, in terms of systematically addressing the fundamental drivers of biodiversity loss. Industrial and mining development is a significant cause of protected area failure and downsizing (Watson et al. 2014). In sub-Saharan Africa, oil and gas concessions overlap with the over $17 \%$ of IUCN category 1 and 2 protected areas (the most strictly protected) and more than a quarter of World Heritage Sites (Watson et al. 2014). The same is true for Latin America (e.g. Hope 2016; Norris in press).

'Green grabbing' ("the appropriation of land and resources for environmental ends" (Fairhead et al. 2012) by conservation organizations desperate to secure key territories and extend the protected area network is made easier through alliance with business. Long-standing state-secured powers for the designation of land for nature can be extended to secure new lands for nature, using private sector funds. In a new 'economy of repair', development's damage to nature is addressed by the establishment of new conservation territories in the form of private protected areas, forests set aside for carbon under REDD+, or biodiversity offsets (Fairhead et al. 2012). This allows conservation to extend the area protected, while industry can claim environmental credentials while carrying forwards its projects.

Biodiversity offsetting is just one strategy that draws together the interests of mining companies and conservation organizations. Norris (in press) provides a broader analysis of the ways in which mining company interests in rights below ground coincide with those of a conservation NGO (Conservation International) above ground in Peru. Both use processes of technical assessment to identify value in and 
under the land, and calculations of the value of fictitious commodities (in the form of proven mineral resources and market based conservation agreements) to persuade landholders to cede rights. The financial resources used by Conservation International were provided by the charitable organizations set up by the mining company. The interests of conservation and mining company converge, their 'social license' to operate obtained through collaboration.

Biodiversity offsetting has been a key strategy for addressing what Virah-Sawmy et al. (2014: 143) identify as "the perceived conflict between economically profitable ventures such as mining and natural heritage." The Business and Biodiversity Offsets Program (established in 2004 as a partnership of more than 70 conservation organizations, companies, governments, and financial institutions) defines biodiversity offsets as "measurable conservation outcomes resulting from actions designed to compensate for significant residual adverse biodiversity impacts arising from project development after appropriate prevention and mitigation measures have been taken" (BBOP 2012: 13).

The methods used in such calculations are technically complex, and often problematic (Apostolopoulou and Adams 2017; Bull et al. 2013). Virah-Sawmy et al. (2014) analyse the methods used to calculate an offset for the loss of littoral forest in SE Madagascar used by a mine to extract the mineral ilmenite (used in chemical manufacture, for example of paints and toothpaste). For Rio Tinto and its derivatives in SE Madagascar, the loss of biodiversity was "both a risk and an opportunity" (Seagle 2012: 453). What Seagle (2012: 448) describes as the "performance of sustainability" helped the company acquire the concession and helped legitimize the subsequent mining operation (Mulligan 2009). Land was set aside for protected areas within the concession (but away from the mining area), and NGOs and scientists were recruited to survey them and help develop a tourism industry. Conservation organizations and the mining company shared media and narrative and media materials, their websites telling the same story using virtually identical imagery and language (Seagle 2012). A new narrative was developed that focused on smallholders as causes of forest loss. Biodiversity offsets outside the mining zone altogether (for example in the hill forests of Tsitongambarika) effectively exported the forest loss problem and made it the responsibility of smallholders. In their "conservation work", which the mining company helped the conservation organizations to promote "rational resource use" by local farmers, effectively "enforcing conservation" (Seagle 2012: 456). Seagle comments that "mining-conservation partnerships appear to involve the swapping of media, sustainability discourses, land and financial resources" (Seagle 2012: 469).

Not all environmental NGOs have such close links with corporations. Hoffman (2009) undertook a network analysis of relationships between 69 of the largest environmental NGOs registered in the USA and corporations listed on their websites. He identified five clusters of NGOs, mediators (central to the corporate network with diverse sectoral ties, pragmatic and tightly connected); bridges (central to the network but with a narrow range of ties, channelling between specific corporate and the rest of the network), independents (at the periphery of the network but with diverse ties, giving them wide contacts and limited influence), captives (also at the periphery of the network but with few specific ties to specific sectors, and hence localized influence) and isolates (effectively outside the network with no corporate partners: independent but without specific influence). Conservation organizations (one of three categories of NGO interest, the others being 'pollution control and 'environmental protection') were mostly central to the corporate network: 73 per cent of conservation NGOs had ties to business, compared to 33\% of those working in environmental protection and $10 \%$ of those in pollution control (Hoffman 2009). NGOs with business ties had larger budgets (US\$24.3m compared to US $\$ 7.6 \mathrm{~m}$ ), and membership. But they risked loss of autonomy.

Some environmental organisations have made very public objections to corporate links. There were, for example, angry interventions from the floor at the plenary session of the World Parks Congress in Durban in 2003 where Shell and the International Council on Mining and Minerals (ICCM) were present, causing floor microphones to be switched off (MacDonald 2010a: 258). Subsequently, Friends of the Earth International withdrew their membership of IUCN in January 2009 because of concern about its corporate partnership with Shell (following fierce debate at 2008 World Conservation Congress in Barcelona on a motion to end this relationship, MacDonald 2010b: 500). Such battles over representation, voice and influence have continued in subsequent international meetings, in struggles to define and renegotiate what conservation is, and is seen to be (MacDonald 2010a; MacDonald and Corson 2012). 
Such decisions may reflect matters of principle for conservationists, but there are also pragmatic factors that they might take into account. Corporate engagements association damage can 'blow back' on conservation organizations, and the brand of an NGO. Thus Vidal (2014) reported in the UK newspaper the Observer that WWF International was accused of "selling its soul" to corporations. In the book Pandaleaks, Wilfred Huisman (2014) argued that partnerships and 'round tables' with global corporations (e.g. Shell, Monsanto, Coca-Cola, HSBC, Cargill, BP, Alcoa and Marine Harvest) simply allow corporate brands to be 'greenwashed.' The importance of such threats to conservation brands depends on the power of anti-corporate sentiment, either nationally or in critical market segments. Klein (2013) argues

...for a long time, forming partnerships with polluters was how the green groups proved they were serious. But the young people demanding divestment - as well as the grassroots groups fighting fossil fuels wherever they are mined, drilled, fracked, burned, piped or shipped - have a different definition of seriousness. They are serious about winning.

Like most fairy tales, the story of Faust is designed to carry moral weight. Faust followed his instinct to partner with the devil. In the short term, he got what he wanted, but the consequences were complicated and far-reaching, affecting Faust himself, those he cared for and the wider world. Fundamentally, there are profound conflicts between the aspirations of corporations and the desire of conservation to protect natural diversity. The reframing of nature as natural capital and the reinvention of conservation as the management of capital flows through market-based instruments, might make a close engagement between neoliberal conservation and corporations look unproblematic. Such a relationship offers the lure of financial resources and power. But conservationists considering getting into bed with corporations should remember the tale of Faust's bargain. The story takes many forms, but in none of them does the pact turn out well.

\section{References}

Adams, R. 2015. Greens fighting Pebble mine are helping Rio Tinto, Anglo-American and BHP Billiton. Atomic Insights 21 May (http://atomicinsights.com/greens-fighting-pebble-mine-are-helping-rio-tintoanglo-american-and-bhp-billiton/, last accessed 20 November 2015).

Adams, W.M. 2004. Against extinction: the story of conservation. London: Earthscan.

Adams, W.M. 2009. Green development: environment and sustainability in a developing world. 3rd ed. London: Routledge.

Apostolopoulou, E. and W.M. Adams. 2017. Biodiversity offsetting and conservation: reframing nature to save it. Oryx 51(1): 23-31.

Arboleda, M. in press 2015. In the nature of the non-city: expanded infrastructural networks and the political ecology of planetary urbanisation. Antipode

Asafu-Adjaye, J., L. Blomquist, S. Brand, B.W. Brook, R. Defries, E. Ellis, C. Foreman, D. Keith, M. Lewis, M. Lynas, T. Nordhaus, R. Pielke, R. Pritzker, J. Roy, M. Sagoff, M. Shellenberger, R. Stone and P. Teague. 2015. An ecomodernist manifesto. www.ecomodernism.org/

Bakker, P. 2012. Speech to meeting of the World Business Council for Sustainable Development Lisbon, October 2, 2012 http://www.wbcsd.org/Pages/EDocument/EDocumentDetails.aspx?ID=15008\&NoSearchContextKey =true.

BBOP. 2012. Standard on biodiversity offsets. Washington, D.C: Business and Biodiversity Offsets Programme.

Braun, B. 2015. New materialisms and neoliberal natures. 2013. Antipode RGS-IBG Lecture 2013. Antipode 47: 1-14. lecture

Brockington, D. 2012. A radically conservative vision? The challenge of UNEP's Towards a green economy. Development and Change 43(1):409-422. 
Brockington, D. and R. Duffy. 2010. Capitalism and conservation: the production and reproduction of biodiversity conservation. Antipode 42: 469-484. Researchgate

Brockington, D., R. Duffy and J. Igoe. 2008. Nature unbound: conservation, capitalism and the future of protected areas. London: Earthscan.

Bull, J.W., K.B. Suttle, A. Gordon, N.J. Singh and E.J. Milner-Gulland. 2013. Biodiversity offsets in theory and practice. Oryx 47: 369-380.

Büscher, B., S. Sullivan, K. Neves, J. Igoe and D. Brockington. 2012. Towards a synthesized critique of neoliberal biodiversity conservation. Capitalism, Nature Socialism 23: 4-30.

Castree, N. and G. Henderson. 2014. The capitalist mode of conservation, neoliberalism and the ecology of value. New Proposals: Journal of Marxism and Interdisciplinary Inquiry 7(1): 16-37.

Chapin, M. 2004. A challenge to conservationists. World Watch 17(6): 17-31.

Colchester, M. 2003. The politics of parks: indigenous peoples assert their rights against mining, markets and tourism. Multinational Monitor 24 (11).

Conservation International. 2008. The Conservation International Rio Tinto partnership. London, Washington D.C. and Melbourne: Conservation International and Rio Tinto.

Corson, C. and K.I. MacDonald. 2012. Enclosing the global commons: the convention on biological; diversity and green grabbing. The Journal of Peasant Studies 39: 263-283. Researchgate

Corson, C., B. Brady, A. Zuber, J. Lord and A. Kim. 2015. The right to resist: disciplining civil society at Rio+20. Journal Peasant Studies 42 (3/4): 859-878.

Dempsey, J. and D.C. Suarez. 2016. Arrested development? The promises and paradoxes of 'selling nature to save it'. Annals of the American Association of Geographers 106(3): 653-671.

Energy and Biodiversity Initiative (EBI). 2003. Integrating biodiversity conservation into oil and gas development, Washington D.C.: EBI, Conservation International.

Fairhead, J., M. Leach and I. Scoones, 2012. 'Green grabbing: a new appropriation of nature? The Journal of Peasant Studies 39: 237-261.

Foster, J.B. 2000. Marx's ecology: materialism and nature. New York: Monthly Review Press.

Foster, J.B. 1999. Marx's theory of metabolic rift: classical foundations for environmental sociology. The American Journal of Sociology 105: 346-405.

Foster, J.B. 2015. Marxism and ecology: common fonts of a great tradition. Great Transition Initiative.

Goldenburg, S. 2013. Anglo American pulls out of Alaska mines project', The Guardian 16 September. http://www.theguardian.com/environment/2013/sep/16/anglo-american-alaska-gold-mines

Griffiths, J. 2010. Mining, Minerals and Sustainable Development, Executive Brief. Geneva: WBCSD.

Hackett, R. 2015. Offsetting dispossession? Terrestrial conservation offsets and First Nation treaty rights in Alberta, Canada. Geoforum 60: 62-71.

Hackett, R. 2016. 'Shell games', displacement and the reordering of boreal landscapes in Alberta, Canada. Area 48: 153-160.

Hoag, H. 2010. Confronting the biodiversity crisis. Nature Reports - Climate Change 4: 5 May.

Hoffman, A.J. 2009. Shades of green. Stanford Social Innovation Review. Spring: 40-49.

Holmes, G. 2012. Biodiversity for billionaires: capitalism, conservation and the role of philanthropy in saving/selling nature. Development and Change 43: 185-203.

Holmes, G. and C.J. Cavanagh. 2016. A review of the social impacts of neoliberal conservation: formations, inequalities, contestations. Geoforum 75: 199-209.

Hope, J. 2016. Losing ground? Extractive-led development versus environmentalism, in the Isiboro Secure Indigenous Territory and National Park (TIPNIS), Bolivia. The Extractive Industries and Society 3(4): 922-929.

Howard, P. 2014a. Working with business. Blog posted 14 July 2014, accessed 1 November 2016 (http://www.fauna-flora.org/initiatives/working-with-business/) 
Howard, P. 2014b. Mining and energy. Blog posted 14 July 2014, accessed 1 November 2016 (http://www.fauna-flora.org/initiatives/anglo-american-partnership/.

Huisman, W. 2014. Pandaleaks: the dark side of the WWF. Pandaleaks, http://www.pandaleaks.org

Igoe, J., Neves, K. and Brockington, D. 2010. A spectacular eco-tour around the historic bloc: Theorising the convergence of biodiversity conservation and capitalist expansion. Antipode 42: 486-512.

IIED. 2002. Breaking new ground: a report of the Mining, Minerals and Sustainable Development (MMSD) Project. London: Earthscan (for the International Institute for Environment and Development and World Business Council for Sustainable Development).

Jeffries, E. 2015. Coming clean. Nature Climate Change 5(2): 93-95.

Klein, N. 2013. The giants of the green world that profit from the planet's destruction. The Guardian 3 May. http://www.theguardian.com/commentisfree/2013/may/03/giants-green-world-profit-planetsdestruction

Kolbert, E. 2014. The sixth extinction: an unnatural history. London: Bloomsbury Publishing.

Lalasz, R., P. Kareiva and M. Marvier. 2011. Conservation in the Anthropocene: beyond solitude and fragility. Breakthrough Journal 2.

Low, N. and B. Gleeson. 1998. Justice, society and nature: an exploration of political ecology. London: Routledge.

Lyon, T.P. and J.W. Maxwell, 2011. Greenwash: corporate environmental disclosure under threat of audit. Journal of Economics and Management Strategy 20: 3-41.

MacDonald, I. 2010a. Business, biodiversity and 'new fields' of conservation: the World Conservation Congress and the renegotiation of organisational order. Conservation and Society 8: 256-275.

MacDonald, K.I. 2010b. The devil is in the (bio)diversity: private sector 'engagement' and the restructuring of biodiversity' conservation. Antipode 42: 513-550.

MacDonald, K.I. 2013. Grabbing 'green': cynical reason, instrumental ethics and the production of 'the green economy'. Human Geography 6: 46-63.

MacDonald, K.I. and C. Corson. 2012. 'TEEB begins now': a virtual moment in the production of natural capital. Development and Change 43:159-184. Academia

Maron, M., R.J. Hobbs, A. Moilanen, J.W. Matthews, K. Christie, T.A. Gardner, D.A. Keithy, D.B. Lindenmeyer and C.A. McAlpine. 2012. Faustian bargains? Restoration realities in the context of biodiversity offset policies. Biological Conservation 155: 141-148.

Marris, E., P. Kareiva, J. Mascaro and E. Ellis. 2011. Hope in the Age of Man. New York Times Dec 7.

Marsh, G.P. 1864. Man and nature: or, physical geography as modified by human action. New York: Scribners. (Harvard University Press, 1965)

McNeilly 2000. The global mining initiative: changing expectations - meeting human needs and aspirations. Text of a talk to 2000 Minerals Industry Seminar, Minerals Council of Australia, June 7, 2000 Available at http://www.wbcsd.org

Moore, J.W. 2011. Transcending the Metabolic Rift: towards a theory of crises in the capitalist worldecology. Journal of Peasant Studies 38(1): 1-46.

Mulligan, P. 1999. Greenwash or blueprint? Rio Tinto in Madagascar. IDS Bulletin 30(3): 50-57.

Neumann, R.P. 1998. Imposing Wilderness: struggles over livelihood and nature preservation in Africa. Berkeley: University of California Press.

Norris, T.B. in press. Shared social license: mining and conservation in the Peruvian Andes. Antipode

Nyul, H. Not dated. AngloAmerican partnership. http://www.fauna-flora.org/initiatives/anglo-americanpartnership/, last accessed 20 November 2015.

OECD. 2011. Towards green growth. Organization for Economic Cooperation and Development, OECD Green Growth Studies. Paris: OECD Publishing. 
Owens, S. 2003. Is there a meaningful definition of sustainability? Plant Genetic Resources: Characterisation and Utilisation 1: 5-9.

Pepper, D. 1993. Eco-socialism: from deep ecology to social justice. London: Routledge.

Pergams, O.R.W., B. Czech, J.C. Haney and D. Nyberg. 2004. Linkage of conservation activity to trends in the U.S. economy. Conservation Biology 18: 1617-1623.

Prudham, S. 2009. Pimping climate change: Richard Branson, global warming, and the performance of green capitalism. Environment and Planning A 41:1594 - 1613.

Robertson, M. 2006. The nature that capital can see: science, state, and market in the commodification of ecosystem services. Environment and Planning D: Society and Space 24: 367-387.

Robinson, J.G. 2011a. Corporate greening: is it significant for biodiversity conservation? Oryx 45(3): 309310.

Robinson, J.G. 2011b. Ethical pluralism, pragmatism, and sustainability in conservation practice. Biological Conservation 144: 958-965.

Rosenbaum, B. 2015. The battle for Arctic oil. Harvard International Review 36(3): March 9.

Rosenfeld Sweeting, A. and A.P. Clark. 2000. Lightening the lode: a guide to responsible large-scale mining. Washington D.C.: Conservation International.

Rosenfeld, A.B., D.L. Gordo and M. Guerin-McManus. 1997. Reinventing the well: minimizing the environmental and social impacts of oil development in the tropics. Washington D.C.: Conservation International

Scales, I.R. 2014. Paying for nature: what every conservationist should know about political economy. Oryx 49: 226-223.

Seagle, C. 2012. Inverting the impacts: mining, conservation and sustainability claims near the Rio Tinto/QMM ilmenite mine in Southeast Madagascar. Journal of Peasant Studies 39: 447-477.

Soulé, M.E. 1985. What is conservation biology? A new synthetic discipline addresses the dynamics and problems of perturbed species, communities, and ecosystems. BioScience 35(11): 727-734.

Soulé, M.E. 2013. The 'new conservation'. Conservation Biology 27: 895-897.

Sullivan, S. 2013. Banking nature? The spectacular financialisation of environmental conservation. Antipode 45(1): 198-217.

Tercek, M. and J.S. Adams, 2015. Nature's fortune: how business and society thrive by investing in nature. Washington D.C.: Island Press.

UN Environment Programme. 2011. Towards a green economy: pathways to sustainable development and poverty eradication. Arendal, Norway: UNEP/GRID.

Veldman, M. 1993. Fantasy, the bomb and the greening of Britain: romantic protest, 1945-1980. Cambridge: Cambridge University Press.

Vidal, J. 2014. WWF International accused of 'selling its soul' to corporations. Observer 4 October. http://www.theguardian.com/environment/2014/oct/04/wwf-international-selling-its-soul-corporations

Virah-Sawmy, M., J. Ebeling and R. Taplin. 2014. Mining and biodiversity offsets: a transparent and sciencebased approach to measure 'no-net-loss'. Journal of Environmental Management 143: 61-70.

Watson, J.E. M., N.I Dudley, D.B. Segan and M. Hockings. 2014. The performance and potential of protected areas. Nature 515: 67-73. Researchgate

World Bank. 2012. Inclusive green growth: the pathway to sustainable development. Washington, D.C.: World Bank. 